\title{
A review of the mosquito species (Diptera: Culicidae) of Bangladesh
}

\author{
Seth R. Irish ${ }^{*}$, Hasan Mohammad Al-Amin², Mohammad Shafiul Alam² and Ralph E. Harbach ${ }^{3}$
}

\begin{abstract}
Background: Diseases caused by mosquito-borne pathogens remain an important source of morbidity and mortality in Bangladesh. To better control the vectors that transmit the agents of disease, and hence the diseases they cause, and to appreciate the diversity of the family Culicidae, it is important to have an up-to-date list of the species present in the country. Original records were collected from a literature review to compile a list of the species recorded in Bangladesh.

Results: Records for 123 species were collected, although some species had only a single record. This is an increase of ten species over the most recent complete list, compiled nearly 30 years ago. Collection records of three additional species are included here: Anopheles pseudowillmori, Armigeres malayi and Mimomyia luzonensis.

Conclusions: While this work constitutes the most complete list of mosquito species collected in Bangladesh, further work is needed to refine this list and understand the distributions of those species within the country. Improved morphological and molecular methods of identification will allow the refinement of this list in years to come.
\end{abstract}

Keywords: Species list, Mosquitoes, Bangladesh, Culicidae

\section{Background}

Several diseases in Bangladesh are caused by mosquitoborne pathogens. Malaria remains an important cause of morbidity and mortality, particularly in the Chittagong Hill tracts and in the border belt areas [1]. Lymphatic filariasis continues to be a problem, despite multiple rounds of mass drug administration [2]. Dengue, Japanese encephalitis, and chikungunya viruses are also transmitted by mosquitoes in Bangladesh [3]. As knowledge of faunal diversity and vector control is often an important component of disease control, it is important to correctly identify and understand the bionomics of the species involved in transmission.

To this end, previous authors have worked to compile lists of the mosquito species present in Bangladesh, by compiling species records from the country. The mosquitoes of Bangladesh have been recorded in several such lists over the past century. James [4], Covell [5, 6], Christophers [7], Barraud [8] and Puri $[9,10]$ described the mosquito fauna of British India, from which some records for locations in present-day Bangladesh can be extracted. After the

\footnotetext{
* Correspondence: sirish@cdc.gov

${ }^{1}$ Entomology Branch, Division of Parasitic Diseases and Malaria, Center for Global Health, Centers for Disease Control and Prevention, 1600 Clifton Rd NE, Atlanta, GA 30329, USA

Full list of author information is available at the end of the article
}

separation of Pakistan and India in 1947, Aslamkhan [11] published checklists for mosquito species, indicating which were found in East Pakistan (Bangladesh). After the independence of Bangladesh in 1971, Ahmed [12] published an updated checklist in 1987, including many new records. More recently, Bashar et al. [13] published a checklist for the Anopheles mosquitoes of Bangladesh, but no comprehensive list of all species of mosquitoes present in the country has been published for nearly 30 years. Over the decades, deforestation and increased agricultural practices may have altered the diversity and abundance of mosquitoes throughout the country [14-16]. Therefore, the aim of this work was to produce an updated list of all mosquito species reportedly present in Bangladesh, with information on their collection.

\section{Methods}

PubMed and the US Armed Forces Pest Management Board Literature Retrieval Service (before it was terminated), were searched using the terms "mosquito" and "Bangladesh." Articles found were searched for the descriptions of the original collections of mosquitoes identified to species. Articles only citing another article's collections (second-hand accounts) were not included. The reference list of collected articles was searched for additional articles. 
National libraries of Bangladesh were also searched for articles. All articles were entered onto a spreadsheet to facilitate calculation of the number of species and the number of records for each species.

Additionally, one of us (HMA) provided records from studies that included the use of light traps (CDC miniature light trap, model 512, John W. Hock Co., Gainesville, Florida, USA), resting collections and BG-Sentinel traps (Biogents AG, Regensberg, Germany) (publications in preparation). The descriptions of the collection sites are provided in the discussion below.

\section{Results}

Records were found for 123 species of Culicidae reported from Bangladesh. The records ranged in date from 1908 to 2016. These species are listed below, alphabetically by genus, subgenus, and species. Aedes species follow the classification provided by Wilkerson et al. [17], whereas all other genera follow the classification provided by the Mosquito Taxonomic Inventory [18]. In accordance with Article 51.3 of the International Code of Zoological Nomenclature, the authorship and date of species names enclosed in parentheses indicate that the species was originally described as a member of a genus other than the one in which it is currently placed, e.g. Aedes aegypti (Linnaeus, 1762) was originally described as Culex aegypti Linnaeus, 1762. The numbers following species names refer to articles where the records were published.

\footnotetext{
Genus Aedeomyia Theobald, 1901

Subgenus Aedeomyia Theobald, 1901

1. Ad. (Ady.) catastica Knab, 1909 [11, 19]

Genus Aedes Meigen, 1818

Subgenus Aedimorphus Theobald, 1903

2. Ae. (Adm.) caecus (Theobald, 1901) [12, 20-22]

3. Ae. (Adm.) pallidostriatus (Theobald, 1907) $[12,20,21]$

4. Ae. (Adm.) punctifemoris (Ludlow, 1921) [12, 20-23]

5. Ae. (Adm.) vexans (Meigen, 1830) $[12,19,24,25]$

Subgenus Christophersiomyia Barraud, 1923

6. Ae. (Chr.) thomsoni (Theobald, 1905) [21]
}

Subgenus Collessius Reinert, Harbach \& Kitching, 2006

7. Ae. (Col.) pseudotaeniatus (Giles, 1901) [26]

Subgenus Dendroskusea Edwards, 1929

8. Ae. (Dsk.) reginae Edwards, 1922 [26]

Subgenus Downsiomyia Vargas, 1950

9. Ae. (Dow.) albolateralis (Theobald, 1908) [27]

10. Ae. (Dow.) niveus (Ludlow, 1903) [12, 24, 28, 29]

Subgenus Edwardsaedes Belkin, 1962

11. Ae. (EdW.) imprimens (Walker, 1861) [30]
(Continued)

Subgenus Fredwardsius Reinert, 2000

12. Ae. (Fre.) vittatus (Bigot, 1861) [26]

Subgenus Hulecoeteomyia Theobald, 1904

13. Ae. (Hul.) chrysolineatus (Theobald, 1907) [12, 20, 28, 31]

Subgenus Kenknightia Reinert, 1990

14. Ae. (Ken.) dissimilis (Leicester, 1908) [12, 28, 32]

Subgenus Mucidus Theobald, 1901

15. Ae. (Muc.) scatophagoides (Theobald, 1901) [12, 20, 21, 24, 27, 31, 33, 34]

Subgenus Neomelaniconion Newstead, 1907

16. Ae. (Neo.) lineatopennis (Ludlow, 1905) [12, 19-21, 24, 31, 35-37]

Subgenus Petermattinglyius Reinert, Harbach \& Kitching, 2009

17. Ae. (Pet.) iyengari Edwards, 1923 [26]

Subgenus Phagomyia Theobald, 1905

18. Ae. (Phg.) assamensis (Theobald, 1908) [11, 12, 21, 24, 27-29, 38, 39]

19. Ae. (Phg.) khazani Edwards, 1922 [8, 12, 24, 26, 28, 29]

20. Ae. (Phg.) lophoventralis (Theobald, 1910) [11, 12, 28, 29, 36, 37]

Subgenus Stegomyia Theobald, 1901

21. Ae. (Stg.) aegypti (Linnaeus, 1762) [12, 25, 26, 28, 34, 36, 37, 40-54]

22. Ae. (Stg.) albopictus (Skuse, 1895) [12, 19-21, 24-28, 31, 36, 37, 40, 42, $44-46,49,50,52-58]$

23. Ae. (Stg.) annandalei (Theobald, 1910) $[11,12,20,26,28]$

24. Ae. (Stg.) desmotes (Giles, 1904) [59]

25. Ae. (Stg.) gardnerii imitator (Leicester, 1908) [60]

26. Ae. (Stg.) w-albus (Theobald, 1905) [12, 28]

Genus Anopheles Meigen, 1818

Subgenus Anopheles Meigen, 1818

27. An. (Ano.) aitkenii James, 1903 [12, 13, 21, 61-64]

28. An. (Ano.) baileyi Edwards, 1929 [7, 9, 63]

29. An. (Ano.) barbirostris van der Wulp, 1884 (s.l.) $[5,6,9,10,12-16,19-21$, $24,31,34-37,40,47,51,61-82]$

30. An. (Ano.) barbumbrosus Strickland \& Chowdhury, 1927 [83]

31. An. (Ano.) bengalensis Puri, $1930[12,34]$

32. An. (Ano.) gigas Giles, 1901 [6, 34, 63, 84]

33. An. (Ano.) nigerrimus Giles, $1900[5,6,12-15,19-21,26,34-37,40,47$, $48,61-64,66,68,69,72,73,82,85]$

34. An. (Ano.) peditaeniatus (Leicester, 1908) $[12,13,15,19,20,24,31,34$, $41,42,47,61-64,66,67,71,86]$

35. An. (Ano.) umbrosus (Theobald, 1903) $[5,6,13-15,35,61-64,68]$

Subgenus Cellia Theobald, 1902

36. An. (Cel.) aconitus Dönitz, 1902 [6, 9, 10, 12-16, 20, 21, 24, 31, 34, 36, $37,48,51,63,68,70,72,73,75-78,80-82,87,88]$

37. An. (Cel.) annularis van der Wulp, 1884 (s.l.) $[5,6,10,12-16,19-21,24$, $25,31,34-37,40-42,45,51,61-65,67-73,75-78,80-82,86,88]$

38. An. (Cel.) baimaii Sallum \& Peyton, 2005 [12-15, 21, 24, 61-64, 81-83, 87, 89-94]

39. An. (Cel.) culicifacies Giles, 1901 (s.l.) [5, 6, 10, 12-14, 16, 20, 21, 24, 25, $31,34,36,37,45,63,70,72,73,87]$

40. An. (Cel.) fluviatilis James, 1902 (s.l.) [5, 6, 12, 13, 24, 34, 48, 61-63, 87] 
(Continued)

41. An. (Cel.) jamesii Theobald, $1901[5,6,10,12-16,20,24,31,34,36,37$, $47,48,61-64,67,68,70,71,73,78,81,82]$

42. An. (Cel.) jeyporiensis James, 1902 [5, 6, 10, 12-15, 20, 21, 24, 31, 61-64, $68,70,73,78,81,82,87]$

43. An. (Cel.) karwari (James, 1903) [6, 9, 12-15, 20, 24, 35, 61-64, 68, 81, 82]

44. An. (Cel.) kochi Dönitz, 1901 [4-6, 10, 12-15, 24, 34, 35, 61-64, 68, 70, $71,73,81-83,85,87]$

45. An. (Cel.) maculatus Theobald, 1901 [12-15, 24, 34, 61-64, 68, 81]

46. An. (Cel.) majidi Young \& Majid, 1928 [12, 13, 24, 63]

47. An. (Cel.) minimus Theobald, 1901 (s.l.) [6, 12-15, 24, 61-64, 68, 70, 77 , $78,80,82,87,95,96]$

48. An. (Cel.) nivipes (Theobald, 1903) [13-15, 62, 64]

49. An. (Cel.) pallidus Theobald, 1901 [6, 10, 12, 13, 16, 20, 24, 34, 61-64, $70,72,73,77,80]$

50. An. (Cel.) philippinensis Ludlow, $1902[5,6,10,12,13,15,16,20,24$ $31,34,35,61-64,68,70-73,77,78,80-82,87,93,95,97,98]$

51 An. (Cel.) pseudojamesi Strickland \& Chowdhury, 1927 [6, 10, 12, 13, $16,35-37,62-64,70-73,77,78]$

52. An. (Cel.) pseudowillmori (Theobald, 1910) [Al-Amin, in preparation]

53. An. (Cel.) splendidus Koidzumi, 1920 [6, 12, 13, 62, 63, 99]

54. An. (Cel.) stephensi Liston, 1901 [47, 100]

55. An. (Cel.) subpictus Grassi, 1899 (s.l.) [5, 6, 10, 12-16, 19-21, 24, 27, 31 , $34-37,40-42,47,48,51,61-72,77-79,81,82,87,101]$

56. An. (Cel.) sundaicus (Rodenwaldt, 1925) (s.l.) [6, 10, 12, 13, 16, 48, 63, $72,73,77,79,95]$

57. An. (Cel.) tessellatus Theobald, 1901 [5, 6, 10, 12-16, 19, 20, 24, 34, 36, $37,61-64,68,70,72,73,81,83]$

58. An. (Cel.) theobaldi Giles, $1901[5,6]$

59. An. (Cel.) turkhudi Liston, $1901[14,48]$

60. An. (Cel.) vagus Dönitz, 1902 [6, 9, 10, 12-16, 19-21, 24-26, 31, 34-37, $40-42,47,48,51,61-72,75-78,80,82,86-88]$

61. An. (Cel.) varuna lyengar, 1924 [6, 10, 12-16, 19, 20, 24, 34, 48, 61-63, $68,70,72,73,77,82,87]$

62. An. (Cel.) willmori (James, 1903) [6, 12-15, 24, 62-64, 68]

\section{Genus Armigeres Theobald, 1901}

\section{Subgenus Armigeres Theobald, 1901}

63. Ar. (Arm.) kesseli Ramalingam, 1987 [19]

64. Ar. (Arm.) kuchingensis Edwards, 1915 [12, 19, 20, 24, 28, 35-37, 41 , $42,47,48]$

65. Ar. (Arm.) malayi (Theobald, 1901) [Al-Amin, in preparation]

66. Ar. (Arm.) subalbatus (Coquillett, 1898) [12, 19-21, 24-28, 34, 36, 37, $40-42,44,45,50,51,55,65,66,86,102]$

67. Ar. (Arm.) theobaldi Barraud, 1934 [103]

\section{Subgenus Leicesteria Theobald, 1904}

68. Ar. (Lei.) annulitarsis (Leicester, 1908) [12]

69. Ar. (Lei.) dentatus Barraud, 1927 [12]

70. Ar. (Lei.) digitatus (Edwards, 1914) $[12,24,31]$

71. Ar. (Lei.) flavus (Leicester, 1908) $[11,12,24,34,102]$

72 Ar. (Lei.) inchoatus Barraud, 1927 [12]

73. Ar. (Lei.) magnus (Theobald, 1908) [11, 12, 20, 21, 24, 27, 102]
(Continued)

74. Ar. (Lei.) omissus (Edwards, 1914) [12]

\section{Genus Coquillettidia Dyar, 1905}

Subgenus Coquillettidia Dyar, 1905

75. Cq. (Coq.) crassipes (van der Wulp, 1881) $[12,19,20,24,27,31,48,104]$

76. Cq. (Coq.) ochracea (Theobald, 1903) $[12,104]$

\section{Genus Culex Linnaeus, 1758}

\section{Subgenus Culex Linnaeus, 1758}

77. Cx. (Cux.) annulus Theobald, 1901 [35, 47, 48]

78. Cx. (Cux.) fuscocephala Theobald, $1907[12,19-21,24-26,31,35-37$, $41,42,44,45,48,50,51,65-67,86,105-108]$

79. Cx. (Cux.) gelidus Theobald, 1901 [12, 19-21, 24, 25, 27, 31, 34-37, 40-42, $50,51,55,65-67,86,106,109]$

80. CX. (Cux.) hutchinsoni Barraud, 1924 [12, 19, 34, 35, 47, 48, 50]

81. CX. (CuX.) mimulus Edwards, 1915 [12, 35, 66, 108, 109]

82. CX. (Cux.) pseudovishnui Colless, 1957 [12, 19, 20, 34, 108]

83. Cx. (Cux.) quinquefasciatus Say, 1823 [12, 19-21, 24-28, 31, 34-37, 40-42, $44-48,50,51,55,57,65-67,108,110-114]$

84. CX. (CuX.) sitiens Wiedemann, 1828 [27, 34, 47]

85. CX. (CuX.) theileri Theobald, 1903 [21]

86. CX. (Cux.) tritaeniorhynchus Giles, 1901 [12, 19-21, 24, 25, 31, 34-37. $40-42,45,50,51,55,65-67,86,108,109,115]$

87. CX. (Cux.) vagans Wiedemann, 1828 [21]

88. Cx. (Cux.) vishnui Theobald, 1901 [12, 19, 20, 24-27, 31, 34, 35, 41, 42, $50,65,67,83,86,108,109]$

89. Cx. (Cux.) whitei Barraud, 1923 [36, 37, 108]

90. Cx. (Cux.) whitmorei (Giles, 1904) [12, 19-21, 24, 31, 34-37, 86, 108]

\section{Subgenus Culiciomyia Theobald, 1907}

91. Cx. (Cui.) fragilis Ludlow, 1903

92. CX. (Cui.) nigropunctatus Edwards, 1926 [8, 12]

93. CX. (Cui.) pallidothorax Theobald, 1905 [12, 24, 26, 116]

94. Cx. (Cui.) pullus Theobald, 1905 [116]

\section{Subgenus Eumelanomyia Theobald, 1909}

95. CX. (Eum.) brevipalpis (Giles, 1902) [12, 24, 26, 28, 117]

96. CX. (Eum.) malayi (Leicester, 1908) [12, 24]

Subgenus Lophoceraomyia Theobald, 1905

97. CX. (Lop.) minutissimus (Theobald, 1907) [12]

\section{Subgenus Oculeomyia Theobald, 1907}

98. CX. (Ocu.) bitaeniorhynchus Giles, 1901 [12, 19-21, 24, 27, 31, 34-37, $41,42,51,55,65-67,86,108,109]$

99. CX. (Ocu.) epidesmus (Theobald, 1910) [12, 19-21, 24, 31, 34, 35, 47, 48, 108] 100. CX. (Ocu.) infula Theobald, 1901 [19, 27, 108, 118]

101. Cx. (Ocu.) sinensis Theobald, 1903 [12, 19-21, 24, 31, 34, 35, 66, 86]

Genus Ficalbia Theobald, 1903

102. Fi. minima (Theobald, 1901) $[8,12,27,33,34,36,37,119]$

Genus Heizmannia Ludlow, 1905

Subgenus Heizmannia Ludlow, 1905

103. Hz. (Hez.) covelli Barraud, 1929 [26] 
(Continued)

Genus Lutzia Theobald, 1903
Subgenus Metalutzia Tanaka, 2003
04. Lt. (M/t.) fuscana (Wiedemann, 1820) [12, 19, 20, 24, 28, 31, 34, 36,
37, 41, 42, 120]
05. Lt. (M/t.) halifaxii (Theobald, 1903) [12, 34, 83]

Genus Malaya Leicester, 1908

106. Ml. genurostris Leicester, 1908 [8, 12, 20, 24, 28, 121]

107. MI. jacobsoni (Edwards, 1930) [8]

Genus Mansonia Blanchard, 1901

Subgenus Mansonioides Theobald, 1907

108. Ma. (Mnd.) annulata Leicester, 1908 [19]

109. Ma. (Mnd.) annulifera (Theobald, 1901) [11, 12, 19-21, 24, 25, 27, 31, $34-37,41,42,45,50,65,67,104]$

110. Ma. (Mnd.) dives (Schiner, 1868) [12, 104]

111. Ma. (Mnd.) indiana Edwards, 1930 [12, 19-21, 24, 31, 34, 35, 50, 65]

112. Ma. (Mnd.) uniformis (Theobald, 1901) [12, 19-21, 24, 25, 27, 31, 34-37, $41,42,45,50,55,65,67,104]$

Genus Mimomyia Theobald, 1903

Subgenus Etorleptiomyia Theobald, 1904

113. Mi. (Eto.) luzonensis (Ludlow, 1905) [Al-Amin, in preparation]

Subgenus Mimomyia Theobald, 1903

114. Mi. (Mim.) chamberlaini Ludlow, 1904 [12, 33, 40, 122]

115. Mi. (Mim.) hybrida (Leicester, 1908) $[8,119]$

Genus Orthopodomyia Theobald, 1904

116. Or. anopheloides (Giles, 1903) [26, 123, 124]

Genus Toxorhynchites Theobald, 1901

Subgenus Toxorhynchites Theobald, 1901

117. Tx. (Tox.) bengalensis Rosenberg \& Evenhuis, 1985 [125]

118. Tx. (Tox.) splendens (Wiedemann, 1819) $[12,26,28,36,45,126,127]$

Genus Tripteroides Giles, 1904

Subgenus Rachionotomyia Theobald, 1905

119. Tp. (Rah.) aranoides (Theobald, 1901) [12, 21, 24, 28,47]

Genus Uranotaenia Lynch Arribálzaga, 1891

Subgenus Pseudoficalbia Theobald, 1912

120. Ur. (PfC.) novobscura Barraud, 1934 [12]

Subgenus Uranotaenia Lynch Arribálzaga, 1891

121. Ur. (Ura.) campestris Leicester, 1908 [12, 20]

122. Ur. (Ura.) rampae Peyton \& Klein, 1970 [19]

Genus Verrallina Theobald, 1903

Subgenus Neomacleaya Theobald, 1907

123. Ve. (Nma.) andamanensis (Edwards, 1922) $[8,27,128]$

\section{Discussion}

A need for improved knowledge of the mosquito species present in Bangladesh has led to the updated list presented here. In some cases previously known species have been found to be species complexes, while in other cases the names of species have been changed or subspecies elevated to species status. In several cases, new collections have resulted in species representing new country records being added to the list.

Among the listed mosquitoes, Anopheles species complexes that are worthy of note here include the Subpictus, Culicifacies, Sundaicus, Annularis, Barbirostris, Fluviatilis, Maculatus, Minimus, and Dirus Complexes. The Subpictus Complex includes four sibling species (informally designated species A, B, C, and D), which are distinguishable based on morphological, chromosomal, and molecular differences $[129,130]$. As of yet, no determination has been made of which species of the Subpictus Complex are present in Bangladesh. Anopheles culicifacies is an important malaria vector in the Indian Sub-continent, but its importance in Bangladesh appears to be limited. The Culicifacies Complex is comprised of species A, B, C, D, and E [131]. Little is known of the species present in Bangladesh, particularly as very few specimens have been found in the past 20 years [22, 63], but recently species B, C, and E were found in Kuhalong, near Bandarban town [14]. The Sundaicus Complex comprises four coastal species: An. sundaicus, An. epiroticus, An. sundaicus D, and An. sundaicus E [132]. While it would appear that An. epiroticus is most likely the species present in coastal areas of Bangladesh, due to the limited geographic provenance of the other species, this awaits confirmation using molecular methods [132]. Anopheles annularis is a complex of two species, A and B [133], which can be distinguished using chromosomal or molecular methods [134]. The Fluviatilis Complex is composed of four sibling species, S, T, U, and V [135], but it is not known which species are present in Bangladesh. The Maculatus Complex (a.k.a. Maculatus Group) consists of nine species, but Anopheles maculatus is comprised of chromosomal forms B and $\mathrm{E}$ [136, 137]. Rongnoparut et al. [138] stated that chromosomal form B is found north of $13^{\circ} \mathrm{N}$, but further work on the group is necessary to know which members are present in Bangladesh. The Barbirostris Complex is composed of seven formally named species, but it seems more species will be added [139, 140]. Only An. barbirostris (s.l.) has been reported from Bangladesh, but it is clear that more work is needed to know which species of the complex are present in the country. The Minimus Complex includes three species: An. harrisoni, An. minimus and An. yaeyamaensis (known only from Japan). Anopheles minimus (s.l.) has been found in Bangladesh [14], but further work is needed to know if $A n$. harrisoni (previously known as species $\mathrm{C}$ ) is present in the country [141]. Finally, the Dirus Complex comprises seven species, of which it appears An. baimaii is the species present in Bangladesh [14, 92, 142]. 
Some of the species included in the most recent previous list published by Ahmed [12] have undergone taxonomic changes. Anopheles gigas var. baileyi was elevated to species status by Harrison et al. [143] and is now known as Anopheles baileyi. Similarly, Anopheles maculatus var. willmori (as willmorei) was restored to species status by Rattanarithikul \& Green [144] and is now known as An. willmori. Anopheles pseudojamesi is the current name (senior synonym) of the formerly accepted An. ramsayi [79]. Culex afridi was synonymized with Cx. infula [109]. Culex quinquefasciatus was listed as "Culex pipiens quinquefasciatus" in the list provided by Ahmed, but $C x$. quinquefasciatus is now accepted as a distinct species $[145,146]$. The species formerly known as $C x$. fuscanus and $C x$. halifaxii are now included in the genus Lutzia as Lt. fuscana and Lt. halifaxii, respectively [147].

There are a number of species that have only been reported in Bangladesh since the list of Ahmed [12]. Larvae of Ae. gardnerii imitator were collected from a tree hole in a botanical garden in Dhaka during 2004 [60]. Adults of Ar. kesseli were taken in resting collections and light traps in Rajshahi Division [19], and adults of $\mathrm{Ar}$. theobaldi were collected in a forested area in Habiganj district (Sylhet Division) [103]. Culex annulus has been collected in Habiganj and Moulavibazar districts in Sylhet Division, as well as on St. Martin's Island, and in the Sundarbans [35, 47, 48]. Two adults of $M a$. annulata and three of Ur. rampae were collected in light traps in Rajshahi Division [19]. Culex fragilis was collected in resting catches in Patrokhola tea garden, Moulavibazar (Sylhet Division) [35]. Additionally, one of us (HMA) recently identified three species new to Bangladesh, which will be reported in publications currently in preparation. Anopheles pseudowillmori were collected in light traps placed in a room with sleeping people (18:00 to 06:00). Nine specimens were collected in Kuhalong and Rajbila unions of Bandarban district between 2009 and 2012. Three Ar. malayi females were collected in BG-Sentinel traps that were placed indoors in Rajshahi and Chapai Nawabganj districts between November 2014 and September 2015. Mimomyia luzonensis was collected using the same method in Dhaka and Chapai Nawabganj districts, and four specimens were collected between September 2014 and September 2015.

Two species listed in Ahmed [12] are excluded from the list. Ahmed [12] listed Ae. pipersalatus with reference to Barraud [30]. In the older reference, a record is provided for Madhupur in Bengal, attributed to Charles Paiva, an entomologist educated in Calcutta, who then took up a position at the Indian Museum in Calcutta where he worked until his death in 1919 [148]. There is a sub-district called Madhupur near Dhaka in Bangladesh, however, there is also a Madhupur in West
Bengal in India. As we could not find any further evidence to which Madhupur was intended, and as no further records of Ae. pipersalatus in Bangladesh were found, we have removed this species from the list of species known to occur in the country. We have also removed the separate listing of An. gigas subspecies simlensis [149], which has been reported only once, from Rangpur [6], as it is represented by An. gigas in the species list.

Armigeres obturbans has been listed in several records, but it appears that this species was regularly confused with the common Ar. subalbatus. Furthermore, Thurman [150] noted that the distribution of Ar. obturbans is limited to Sulawesi, so it seems likely that the records for Ar. obturbans in Bangladesh refer to Ar. subalbatus. We have therefore removed Ar. obturbans from the species list for Bangladesh.

The inclusion of certain species in previous lists was the result of single records. This was the case for Ae. thomsoni, Ae. pseudotaeniatus, Ae. reginae, Ae. albolateralis, Ae. imprimens, Ae. vittatus, Ae. iyengari, Ae. desmotes, Ae. gardnerii imitator, An. barbumbrosus, Ar. kesseli, Ar. theobaldi, Ar. annulitarsis, Ar. dentatus, Ar. inchoatus, Ar. omissus, Cx. fragilis, Cx. theileri, $C x$. vagans, Cx. pullus, Cx. minutissimus, $\mathrm{Hz}$. covelli, Ml. jacobsoni, Ma. annulata, Tx. bengalensis, Ur. novobscura, and Ur. rampae. While several of these species represent recent records for Bangladesh, others, such as Ae. pseudotaeniatus, Ae. reginae, Ae. albolateralis, Ae. imprimens, Ae. vittatus, Ae. iyengari, Cx. pullus, $\mathrm{Hz}$. covelli, and $M l$. jacobsoni, have not been found in Bangladesh in the past 50 years. Further collections, particularly of culicines, would be helpful in improving our knowledge of the species that are present in the country.

\section{Conclusions}

The list provided here is the most complete list compiled since the work of Ahmed [12], nearly 30 years ago. The up-dated list will serve as a basis for the development of identification keys and will hopefully spur on research on the bionomics of these species. These tools will be important for the reduction of diseases in Bangladesh caused by mosquito-borne pathogens.

\section{Acknowledgements}

Not applicable.

\section{Funding}

International Centre for Diarrhoeal Disease Research, Bangladesh (icddr,b) is grateful to the Governments of Bangladesh, Canada, Sweden and the UK for providing core/unrestricted support. The publishing costs for this manuscript were paid by the President's Malaria Initiative (USAID/CDC).

Availability of data and material

Not applicable. 


\section{Authors' contributions}

SRI conceived the study; SRI and HMA drafted the manuscript; MSA and REH critically revised the manuscript for intellectual and taxonomic content. SRI is the guarantor of the paper. All authors read and approved the final manuscript.

\section{Competing interests}

The authors declare that they have no competing interests.

\section{Consent for publication}

Not applicable.

\section{Ethics approval and consent to participate}

Not applicable.

\section{Author details}

${ }^{1}$ Entomology Branch, Division of Parasitic Diseases and Malaria, Center for Global Health, Centers for Disease Control and Prevention, 1600 Clifton Rd NE, Atlanta, GA 30329, USA. ${ }^{2}$ International Centre for Diarrhoeal Disease Research Bangladesh (icddr,b), 68 Shaheed Tajuddin Ahmed Sarani, Mohakhali, Dhaka 1212, Bangladesh. ${ }^{3}$ Department of Life Sciences, Natural History Museum, Cromwell Road, London SW7 5BD, UK.

\section{Received: 22 July 2016 Accepted: 13 October 2016}

\section{Published online: 22 October 2016}

\section{References}

1. Haque U, Overgaard HJ, Clements AC, Norris DE, Islam N, Karim J, et al. Malaria burden and control in Bangladesh and prospects for elimination: an epidemiological and economic assessment. Lancet Glob Health. 2014:2:e98-105.

2. Hafiz I, Graves P, Haq R, Flora MS, Kelly-Hope LA. Clinical case estimates of lymphatic filariasis in an endemic district of Bangladesh after a decade of mass drug administration. T Roy Soc Trop Med Hyg. 2015;109:700-9.

3. WHO. Bibliography of scientific publications on vector-borne diseases from WHO south-east Asia region 2009-2013. New Delhi: World Health Organization; 2014.

4. James SP. Notes on mosquitoes. Paludism (Simla). 1910;1:33-8.

5. Covell G. The distribution of anopheline mosquitoes of India and Ceylon. Ind Med Res Mem. 1927;5:1-85.

6. Covell G. The distribution of anopheline mosquitoes in India and Ceylon. Additional records, 1926-1930. Rec Mal Surv Ind. 1931:2:225-68.

7. Christophers SR. The fauna of British India, including Ceylon and Burma. Diptera Vol. 4, Family Culicidae. Tribe Anophelini. London: Taylor \& Francis; 1933.

8. Barraud PJ. The fauna of British India, including Ceylon and Burma, Diptera Vol. 5, family Culicidae. Tribes megarhinini and culicini. London: Taylor and Francis; 1934.

9. Puri IM. The distribution of anopheline mosquitoes in India: additional records, 1931-1935. Rec Mal Surv Ind. 1936;6:177-211.

10. Puri IM. The distribution of anopheline mosquitoes in India, Pakistan, Ceylon and Burma. Part V: additional records 1936-1947. Ind J Malariol. 1948:2:67-107.

11. Aslamkhan M. The mosquitoes of Pakistan. I A Checklist Mosq News. 1971:3:147-59.

12. Ahmed TU. Checklist of the mosquitoes of Bangladesh. Mosq Syst. 1987;19:187-200.

13. Bashar K, Mahmud KH, Reza MS, Goda P, Rain FF, Jesmin M, et al. Revised checklist and distribution maps of Anopheles (Insecta: Diptera: Culicidae: Anophelinae) mosquitoes of Bangladesh. Check List. 2013;9:211-24.

14. Alam MS, Chakma S, Khan WA, Glass GE, Mohon AN, Elahi R, et al. Diversity of anopheline species and their Plasmodium infection status in rural Bandarban, Bangladesh. Parasit Vectors. 2012;5:150.

15. Al-Amin HM, Elahi R, Mohon AN, Kafi MA, Chakma S, Lord JS, et al. Role of underappreciated vectors in malaria transmission in an endemic region of Bangladesh-India border. Parasit Vectors. 2015;8:195.

16. Elias M, Bar MA, Farooque MMSA. A note on entomological studies in malarious areas of southwestern districts of Bangladesh. J Prevent Soc Med. 1982;1:59-64.

17. Wilkerson RC, Linton YM, Fonseca DM, Schultz TR, Price DC, Strickman DA Making mosquito taxonomy useful: a stable classification of tribe aedini that balances utility with current knowledge of evolutionary relationships. PLoS One. 2015:10:e0133602.

18. Mosquito Taxonomic Inventory [http://mosquito-taxonomic-inventory.info/]. Accessed 15 Aug 2016.

19. Lord JS, Al-Amin HM, Chakma S, Alam MS, Gurley ES, Pulliam JR. Sampling design influences the observed dominance of Culex tritaeniorhynchus: considerations for future studies of Japanese encephalitis virus transmission. PLoS Negl Trop Dis. 2016;10:e0004249.

20. Ahmed TU, Jannat KN, Akhter S, Ahmed RU, Dewan ZU, Khoda ME. Studies on mosquitoes of Thakurgaon district, Bangladesh. Bangladesh J Entomol. 2004:14:47-62.

21. Aslamkhan M, Wolfe MS. Bancroftian filariasis in two villages in Dinajpur District, East Pakistan. II. Entomological investigations. Am J Trop Med Hyg. 1972;21:30-7.

22. Reinert JF. Contributions to the mosquito fauna of southeast Asia XVI. Genus Aedes Meigen, subgenus Aedimorphus Theobald in southeast Asia. Contrib Am Entomol Inst. 1973:9:1-218.

23. Aslamkhan M. A redescription of Aedes (Aedimorphus) punctifemoris (Ludlow) from Pakistan. Biologia. 1971:17:65.

24. Ahmed TU, Joshi GP, Ahmed RU, Akhter S, Hakim MA, Bhuiyan MRK, et al. Observation on the abundance of mosquitoes in a teagarden area of Bangladesh. J Zool. 1991;6:119-34.

25. Bashar K. Status and distribution of vectors mosquito fauna in Jahangirnagar University (JU) campus. Bangladesh J Life Sci. 2006;18:35-44.

26. Nasiruddin M. Mosquitoes breeding in tree-holes and bamboo stumps in Dacca (East Pakistan). Pak J Health. 1952;2:110-2

27. Theobald FV. First report on the collection of Culicidae and Corethridae in the Indian Museum, Calcutta, with descriptions of new genera and species. Rec Indian Mus. 1908;2:287-302.

28. Ahmed TU, Joshi GP, Ahmed RU, Dewan ZU, Chowdhury MS, Akhter S. Container habitat mosquitoes of Bangladesh. J Zool. 1990;5:7-16.

29. Barraud PJ. A revision of the culicine mosquitoes of India. Part VI. Some Indian species of the genus Finlaya Theo. Adult stage. Indian J Med Res. 1923;11:480-9.

30. Barraud PJ. A revision of the culicine mosquitoes of India. Part XXIII. The genus Aedes (sens. lat) and the classification of the subgenera. Descriptions of the Indian species of Aedes (Aedimorphus), Aedes (Ochlerotatus) and Aedes (Banksinella) with notes on Aedes (Stegomyia) variegatus. Indian J Med Res. 1928;15:663-4.

31. Ahmed TU, Joshi GP, Ahmed RU, Begum MN, Akhter S, Khoda ME. Study on seasonal density of common mosquitoes in jungle area of Modhupur, Tangail. J Zool. 1989:4:1-14.

32. Barraud PJ. A revision of the culicine mosquitoes of India. Part VIII. Further descriptions of Indian species of Finlaya Theo. Indian J Med Res. 1924:11:845-65.

33. Barraud PJ. A revision of the culicine mosquitoes of India. Part XXV. The genera Mucidus, Mimomyia, Ficalbia, Rachionotomyia and Hodgesia. Indian J Med Res. 1929;16:1054-8.

34. Renshaw M, Elias M, Maheswary NP, Hassan MM, Silver JB, Birley MH. A survey of larval and adult mosquitoes on the flood plains of Bangladesh, in relation to flood-control activities. Ann Trop Med Parasit. 1996:90:621-34.

35. Ahmed TU, Nur J, Naved AF. Mosquito populations, including new record, in the tea gardens of Bangladesh. Bangladesh J Entomol. 2009:19:45-60.

36. Ameen M. A systematic account of the insect fauna of Dacca City and its suburbs. 3. Culicidae. J Asiatic Soc Bangladesh. 1971:16:221-5.

37. Ameen M, Moizuddin M. Bionomics of the common mosquitoes of Dacca. J Nat Hist. 1973:7:1-21

38. Barraud PJ. A revision of the culicine mosquitoes of India. Part IV. The larvae of some Indian species of Finlaya Theo. Indian J Med Res. 1923;11:222-3.

39. Barraud PJ. Some new culicine mosquitoes found in India, and a note on Finlaya assamensis (Theo.). Bull Entomol Res. 1923;13:405-8.

40. Ameen M, Huq MF. A systematic account of the insect fauna of Dacca City and its suburbs. 2. Diptera. J Asiatic Soc Pakistan. 1970;15:217-21.

41. Ameen M, Hossain Ml, Khan MDH. Resting behavior, biting activity pattern and host preference of common mosquitoes of Dhaka City. Bangladesh J Zool. 1982:10:35-48.

42. Ameen M, Hossain MI, Khan MDH. Seasonal prevalence of the common mosquitoes of Dhaka city. Dhaka Univ Stud B. 1984:22:79-89.

43. Ameen M, Moizuddin M. Duration of the various developmental stages of Aedes aegypti (L) (Diptera: Culicidae) in Dacca City. Dacca Univ Stud B. 1973;21:15-25. 
44. Bashar K, Shamsuzzaman M, Chowdhury MAK. Container breeding mosquitoes in Dhaka city, Bangladesh. Bangladesh J Life Sci. 2006;18:69-78.

45. Bashar K, Rain FF, Asaduzzaman JM. Surveillance of mosquitoes in some selected parks and gardens of Dhaka city, Bangladesh. Int J Mosq Res. 2014;1:5-9.

46. Hossain M, Chowdhury MAK, Nahar S, Samajpati S. Prevalence of dengue vectors in some rural areas of Narsingdi district, Bangladesh. Bangladesh J Zool. 2002;30:81-6.

47. Jannat KN. Mosquitoes bordering some parts of Sundarban forest, Bangladesh. Bangladesh J Entomol. 2010;20:11-21.

48. Jannat KNE, Ahmed TU. The mosquito fauna, including new records of St. Martin's Island, Bangladesh. Bangladesh J Entomol. 2006;16:67-81.

49. Khan AR. Studies on the breeding habitats and seasonal prevalence of larval population of Aedes aegypti (L.) and Aedes albopictus (Skuse) in Dacca city. Bangladesh Med Res Council Bull. 1980;6:45-52.

50. Khan HR, Islam MM, Akter T, Karim MR, Farid MS. Diversity of mosquitoes and their seasonal fluctuation in two wards of Dhaka city. Dhaka Univ J Biol Sci. 2014;23:17-26.

51. Self LS. Assignment report on mosquito control schemes in the large cities of Bangladesh. WHO project: SEARO 0007. 1-30 November 1973. 1974.

52. Dhar-Chowdhury P, Haque CE, Lindsay R, Hossain S. Socioeconomic and ecological factors influencing Aedes aegypti prevalence, abundance, and distribution in Dhaka, Bangladesh. Am J Trop Med Hyg. 2016;94:1223-33.

53. Ali M, Wagatsuma $Y$, Emch $M$, Breiman RF. Use of a geographic information system for defining spatial risk for dengue transmission in Bangladesh: role for Aedes albopictus in an urban outbreak. Am J Trop Med Hyg. 2003;69:634-40

54. Ferdousi F, Yoshimatsu S, Ma E, Sohel N, Wagatsuma Y. Identification of essential containers for Aedes larval breeding to control dengue in Dhaka. Bangladesh Trop Med Health. 2015;43:253-64.

55. Aziz MA, Gorham JR, Gregg MB. "Dacca Fever" - An outbreak of dengue. Pak J Med Res. 1967;6:83-92.

56. Barraud PJ. Notes on some Indian mosquitoes of the subgenus Stegomyia with descriptions of new species. Indian J Med Res. 1931;19:221-7.

57. Khatun S, Chakraborty A, Rahman M, Nasreen Banu N, Rahman MM, Hasan SM, et al. An outbreak of Chikungunya in rural Bangladesh, 2011. PLoS Negl Trop Dis. 2015;9:e0003907.

58. Chowdhury R, Chowdhury V, Faria S, Huda MM, Laila R, Dhar I, et al. How dengue vector Aedes albopictus (Diptera: Culicidae) survive during the dry season in Dhaka City, Bangladesh? J Vector Borne Dis. 2014;51:179-87.

59. Ahmed TU. Aedes (Stg.) desmotes. In: Ahmed ZU, editor. Encyclopedia of flora and fauna of Bangladesh vol. 21. Dhaka: Asiatic Society of Bangladesh; 2009. p. 250-1.

60. Ahmed TU. Aedes (Stg.) gardnerii imitator. In: Ahmed ZU, editor. Encyclopedia of flora and fauna of Bangladesh vol. 21. Dhaka: Asiatic Society of Bangladesh; 2009. p. 251-2.

61. Bashar K, Tuno N, Ahmed TU, Howlader AJ. Blood-feeding patterns of Anopheles mosquitoes in a malaria-endemic area of Bangladesh. Parasit Vectors. 2012;5:39.

62. Bashar K, Tuno N, Ahmed TU, Howlader AJ. False positivity of circumsporozoite protein (CSP)-ELISA in zoophilic anophelines in Bangladesh. Acta Trop. 2013;125:220-5.

63. Chowdhury NN, Ahmed TU, Shah MH, Chowdhury B, Ferdous E, Khan RK, et al. Distribution and relative prevalence of anophelines in malaria endemic districts of Bangladesh. Bangladesh J Entomol. 2011;21:89-100.

64. Bashar K, Tuno N. Seasonal abundance of Anopheles mosquitoes and their association with meteorological factors and malaria incidence in Bangladesh. Parasit Vectors. 2014;7:442.

65. Ahmed TU, Begum MN, Khoda ME. Seasonal prevalence and filarial infection of Culex quinquefasciatus in Dhaka. J Zool. 1988;3:9-16.

66. Ahmed TU, Islam MM, Rahman S, Lisa LA, Naved AF. Observation of mosquito population in dean stone tea estate, srimangal. Bangladesh J Med Sci. 2001;7:30-7.

67. Ahmed TU, Maheswary NP, Khan NI. Filariasis in mirpur area of Dhaka city. Bangladesh Med Res Council Bull. 1986;12:83-94.

68. Alam MS, Khan MG, Chaudhury N, Deloer S, Nazib F, Bangali AM, et al. Prevalence of anopheline species and their Plasmodium infection status in epidemic-prone border areas of Bangladesh. Malaria J. 2010;9:15.

69. Ameen M, Talukdar MZI. Pupal chaetotaxy of common mosquitoes of Dacca. Beitr Entomol. 1974;24:87-95.
70. Gramiccia G. Final comprehensive report, Pakistan, E. Bengal malaria control demonstration team, Mymensingh district. Pak J Health. 1952;2:61-88.

71. Elias M, Rahman AJ, Mobarak Ali M, Begum J, Chowdhury AR. The ecology of malaria carrying mosquito Anopheles philippinensis Ludlow and its relation to malaria in Bangladesh. Bangladesh Med Res Council Bull. 1987;13:15-28.

72. lyengar MOT. A years' work on dissection of Anopheles for natural malaria infection. J Malar Inst India. 1939;2:105-9.

73. lyengar MOT. Further observations on vectors of malaria in Bengal and notes of the seasonal infectivity of Anopheles. J Malar Inst India. 1940;3:1.

74. Jannat KNE. Anopheles (An.) barbirostris. In: Ahmed ZU, editor. Encyclopedia of flora and fauna of Bangladesh vol. 21. Dhaka: Asiatic Society of Bangladesh; 2009. p. 255-6.

75. Maheswary NP, Majumdar S, Chowdhury AR, Faruque MS, Montanari RM. Incrimination of Anopheles vagus Donitz, 1902 as an epidemic malaria vector in Bangladesh. Ind J Malariol. 1994;31:35-8.

76. Maheswary NP, Habib MA, Elias M. Incrimination of Anopheles aconitus Donitz as a vector of epidemic malaria in Bangladesh. Southeast Asian Trop Med Public Health. 1992;23:798-801.

77. Nasiruddin M. A note on the natural infectivity of mosquitoes in East Pakistan. Pak J Health. 1952;2:113-5.

78. Nasiruddin M. A year's work of the national malaria control teams in east Pakistan (1950). Pak J Health. 1952;1:21-41.

79. Nurul Huda KM. On a collection of mosquitoes from the St. Martin's Island, Bangladesh. Chittagong Univ Stud. 1982;6:47-50.

80. Quraishi MS, Ahmed M, Gramiccia G. Pre-monsoon malaria transmission in the district of Mymensingh, East Pakistan. Bull World Health Organ. 1951;3:673-82.

81. Rosenberg R, Maheswary NP. Forest malaria in Bangladesh. II. Transmission by Anopheles dirus. Am J Trop Med Hyg. 1982;31:183-91.

82. Macan TT. Malaria survey of the Arakan region of Bengal and Burma. Parasitology. 1950;40:290-7.

83. Rosenberg R. Forest malaria in Bangladesh. III. Breeding habits of Anopheles dirus. Am J Trop Med Hyg. 1982;31:192-201.

84. Jannat KNE. Anopheles (An.) gigas. In: Ahmed ZU, editor. Encyclopedia of flora and fauna of Bangladesh vol. 21. Dhaka: Asiatic Society of Bangladesh; 2009. p. 257-8.

85. James SP, Liston WG. A monograph of the anopheline mosquitoes of India. Calcutta: Thacker, Spink \& Co.; 1911

86. Khan AM, Khan AQ, Dobrzynski L, Joshi GP, Myat A. A Japanese encephalitis focus in Bangladesh. J Trop Med Hyg. 1981;84:41-4.

87. Khan AQ, Talibi SA. Epidemiological assessment of malaria transmission in an endemic area of East Pakistan and the significance of congenital immunity. Bull World Health Organ. 1972;46:783-92.

88. Maheswary NP, Khan Z, Molla FR, Haq MI. Incrimination of Anopheles annularis van der Wulp, 1854 as an epidemic malaria vector in Bangladesh. Southeast Asian J Trop Med Public Health. 1993;24:776-8.

89. Elias M, Rahman M. DDT-susceptibility status of malaria vector Anopheles balabacensis balabacensis Baisas (Diptera: Culicidae) in Bangladesh. Bangladesh Med Res Council Bull. 1981;7:1-6.

90. Rahman M, Elias M, Ameen M. Bionomics of Anopheles balabacensis balabacensis Baisas (Diptera: Culicidae) in Bangladesh and its relation to malaria. Bangladesh J Zool. 1977;5:1-23.

91. Sarma DK, Prakash A, O'Loughlin SM, Bhattacharyya DR, Mohapatra PK, Bhattacharjee K, et al. Genetic population structure of the malaria vector Anopheles baimaii in north-east India using mitochondrial DNA. Malaria J. 2012;11:76.

92. Walton C, Handley JM, Tun-Lint W, Collins FH, Harbach RE, Baimai V, et al. Population structure and population history of Anopheles dirus mosquitoes in Southeast Asia. Mol Biol Evol. 2000;17:962-74.

93. Elias M, Maheswary NP, Islam MS, Rahman MK. Susceptibility of the malaria vectors to insecticides in Bangladesh. Bangladesh Med Res Council Bull. 1998;24:1-5.

94. Sallum MA, Peyton EL, Wilkerson RC. Six new species of the Anopheles leucosphyrus group, reinterpretation of An. elegans and vector implications. Med Vet Entomol. 2005:19:158-99.

95. Hussain MZY. The vectors of malaria and malaria transmission in Pakistan. Pak J Health. 1951;1:69-71.

96. Tangin A, Komichi Y, Wagatsuma Y, Rashidul H, Wataya Y, Kim HS. Detection of malaria parasites in mosquitoes from the malaria-endemic area of Chakaria, Bangladesh. Biol Pharm Bull. 2008;31:703-8. 
97. Elias M. Susceptibility of malaria vector Anopheles philippinensis Ludlow (Diptera: Culicidae) to insecticides in Bangladesh. Bangladesh J Zool. 1978;6:153-5.

98. Sur P. Anopheles philippinensis as a natural carrier of the malaria parasites in Bengal. Indian J Med Res. 1928;16:45-7.

99. Jannat KNE. Anopheles (Cel.) splendidus. In: Ahmed ZU, editor. Encyclopedia of flora and fauna of Bangladesh vol. 21. Dhaka: Asiatic Society of Bangladesh; 2009. p. 274-5.

100. Jannat KNE. Anopheles (Cel.) stephensi. In: Ahmed ZU, editor. Encyclopedia of flora and fauna of Bangladesh vol. 21. Dhaka: Asiatic Society of Bangladesh; 2009. p. 275-6.

101. Jannat KNE. Anopheles (Cel.) subpictus. In: Ahmed ZU, editor. Encyclopedia of flora and fauna of Bangladesh vol. 21. Dhaka: Asiatic Society of Bangladesh; 2009. p. 276.

102. Barraud PJ. A revision of the culicine mosquitoes of India. Part XX. The Indian species of Armigeres (including Leicesteria) with descriptions of two new species. Indian J Med Res. 1927;14:537-43.

103. Ahmed TU. Armigeres (Arm.) theobaldi. In: Ahmed ZU, editor. Encyclopedia of flora and fauna of Bangladesh vol. 21. Dhaka: Asiatic Society of Bangladesh; 2009. p. 284-5.

104. Barraud PJ. A revision of the culicine mosquitoes of India. Part XXII. The Indian species of the genus Taeniorhynchus (including Mansonioides), with a description of one new species. Indian J Med Res. 1927;14:556-63.

105. Aslamkhan M. A gynandromorph of Culex fuscocephala Theobald from East Pakistan. Mosq News. 1970;30:271-3.

106. Baker RH, Aslamkhan M. Karyotypes of some Asian mosquitoes of the subfamily Culicinae (Diptera: Culicidae). J Med Entomol. 1969;6:44-52.

107. Barraud PJ. A revision of the culicine mosquitoes of India. Part XII. Further descriptions of Indian species of Culex L. including two new species. Indian J Med Res. 1924;11:1270-2.

108. Sirivanakarn S. A revision of the subgenus Culex in the oriental region (Diptera: Culicidae). Contrib Am Entomol Inst. 1976;12:1-272.

109. Barraud PJ. A revision of the culicine mosquitoes of India. Part XI. Some Indian species of Culex L. Indian J Med Res. 1924;11:984-97.

110. Ameen M, Moizuddin M. Duration of the various developmental stages of Culex pipiens fatigans Wiedemann (Diptera: Culicidae) in Dacca City. Bangladesh J Zool. 1975;1:11-22.

111. Begum MN, Ahmed TU, Khoda ME. Gonotrophic cycle of Culex quinquefasciatus Say (Diptera: Culicidae) in Dhaka. Bangladesh J Zool. 1986; 14:111-5

112. Begum MN, Ahmed TU, Khoda ME. Natural mortality of filarial vector Culex quinquefasciatus Say (Diptera: Culicidae) in Dhaka. Bangladesh J Zool. 1988;16:127-36.

113. Hasan AU, Suguri S, Ahmed SM, Fujimoto C, Harada M, Rahman SM, et al. Molecular phylogeography of Culex quinquefasciatus mosquitoes in centra Bangladesh. Acta Trop. 2009;112:106-14.

114. Ali A, Chowdhury MA, Hossain MI, Mahmud UI A, Habiba DB, Aslam AF. Laboratory evaluation of selected larvicides and insect growth regulators against field-collected Culex quinquefasciatus larvae from urban Dhaka, Bangladesh. J Am Mosq Control Assoc. 1999;15:43-7.

115. Ahmed T, Hayes CG, Baqar S. Comparison of vector competence for West Nile virus of colonized populations of Culex tritaeniorhynchus from southern Asia and the Far East. Southeast Asian J Trop Med Public Health. 1979; 10:498-504.

116. Barraud PJ. A revision of the culicine mosquitoes of India. Part XIV. The Indian species of the subgenus Culiciomyia (Theo.) Edw., including one new species. Indian J Med Res. 1924;12:17-20.

117. Barraud PJ. A revision of the culicine mosquitoes of India. Part XIII. Further descriptions of Indian species of Culex L. including three new species. Indian J Med Res. 1924:11:1277-8.

118. Qutubuddin M. Culex (Culex) afridii sp. n. a new species of mosquito (Diptera: Culicidae) from Dacca, East Pakistan. Mosq News. 1956;16:140-2.

119. Aslamkhan M, Baker RH. Karyotypes of some Anopheles, Ficalbia and Culex mosquitoes of Asia. Pak J Zool. 1969:1:1-7.

120. Barraud PJ. A revision of the culicine mosquitoes of India. Part IX. The Indian species of Lutzia Theo. Indian J Med Res. 1924;11:973-4.

121. Barraud PJ. A revision of the culicine mosquitoes of India. Part XVIII The Indian species of Uranotaenia and Harpagomyia with descriptions of five new species. Indian J Med Res. 1926;14:349.

122. Ameen M, Talukdar MZI. Pupa of Ficalbia (Mimomyia) chamberlaini (Ludlow) (Diptera: Culicidae). Mosq Syst. 1974;6:206-10.
123. Zavortink TJ. Mosquito Studies (Diptera, Culicidae) VIII. A prodrome of the genus Orthopodomyia. Contrib Am Entomol Inst. 1968;3:1-221.

124. Zavortink TJ. Contribution to the mosquito fauna of Southeast Asia IX. The genus Orthopodomyia Theobald in Southeast Asia. Contrib Am Entomol Inst. 1971;7:1-37.

125. Rosenberg R, Evenhuis NL. A new species of Toxorhynchites from Bangladesh. Mosq Syst. 1985;17:36-43.

126. Ameen M, Talukdar MZI. Pupa of Toxorhynchites splendens (Wiedemann) (Diptera: Culicidae). Mosq Syst. 1974;6:206-10.

127. Barraud PJ. A revision of the culicine mosquitoes of India. Part XXVI. The genera Heizmannia, Haemagogus, Topomyia and Megarhinus. Indian J Med Res. 1929;17:277-9.

128. Barraud PJ. A revision of the culicine mosquitoes of India. Part XXIV. The Indian species of the subgenera Skusea and Aedes, with descriptions of eight new species, and remarks on a new method for identifying the females of the subgenus Aedes. Indian J Med Res. 1928;16:368-9.

129. Suguna SG, Rathinam KG, Rajavel AR, Dhanda V. Morphological and chromosomal descriptions of new species in the Anopheles subpictus complex. Med Vet Entomol. 1994;8:88-94.

130. Surendran SN, Sarma DK, Jude PJ, Kemppainen P, Kanthakumaran N, Gajapathy K, et al. Molecular characterization and identification of members of the Anopheles subpictus complex in Sri Lanka. Malaria J. 2013;12:304.

131. Kar I, Subbarao SK, Eapen A, Ravindran J, Satyanarayana TS, Raghavendra K, et al. Evidence for a new malaria vector species, Species E, within the Anopheles culicifacies complex (Diptera: Culicidae). J Med Entomol. 1999;36:595-600.

132. Dusfour I, Blondeau J, Harbach RE, Vythilingham I, Baimai V, Trung HD, et al. Polymerase chain reaction identification of three members of the Anopheles sundaicus (Diptera: Culicidae) complex, malaria vectors in Southeast Asia. J Med Entomol. 2007:44:723-31.

133. Atrie B, Subbarao SK, Pilai MKK, Rao SRV, Sharma VP. Population cytogenetic evidence for sibling species in Anopheles annularis (Diptera: Culicidae). Ann Entomol Soc Am. 1999;92:243-9.

134. Alam MT, Das MK, Dev V, Ansari MA, Sharma YD. Identification of two cryptic species in the Anopheles (Cellia) annularis complex using ribosomal DNA PCR-RFLP. Parasitol Res. 2007:100:943-8.

135. Nanda N, Singh OP, Dua VK, Pandey AC, Nagpal BN, Adak T, Dash AP, Subbarao SK. Population cytogenetic and molecular evidence for existence of a new species in Anopheles fluviatilis complex (Diptera: Culicidae). Infect Genet Evol. 2013;13:218-23.

136. Somboon P, Thongwat D, Harbach RE. Anopheles (Cellia) rampae n. sp., alias chromosomal form $\mathrm{K}$ of the Oriental Maculatus group (Diptera: Culicidae) in southeast Asia. Zootaxa. 2011;2810:47-55

137. Walton C, Somboon P, O'Loughlin SM, Zhang S, Harbach RE, Linton YM, et al. Genetic diversity and molecular identification of mosquito species in the Anopheles maculatus group using the ITS2 region of rDNA. Infect Genet Evol. 2007:7:93-102

138. Rongnoparut $P$, Sirichotpakorn N, Rattanarithikul R, Yaicharoen S, Linthicum KJ. Estimates of gene flow among Anopheles maculatus populations in Thailand using microsatellite analysis. Am J Trop Med Hyg. 1999;60:508-15.

139. Paredes-Esquivel C, Donnelly MJ, Harbach RE, Townson H. A molecular phylogeny of mosquitoes in the Anopheles barbirostris Subgroup reveals cryptic species: implications for identification of disease vectors. Mol Phylogenet Evol. 2009:50:141-51.

140. Taai K, Harbach RE. Systematics of the Anopheles barbirostris species complex (Diptera: Culicidae: Anophelinae) in Thailand. Zool J Linn Soc. 2015;174:244-64.

141. Harbach RE, Garros C, Nguyen DM, Manguin S. Formal taxonomy of species C of the Anopheles minimus sibling species complex (Diptera: Culicidae). Zootaxa. 2007:1654:41-54

142. Manguin S, Garros C, Dusfour I, Harbach RE, Coosemans M. Bionomics, taxonomy, and distribution of the major malaria vector taxa of Anopheles subgenus Cellia in Southeast Asia: an updated review. Infect Genet Evol. 2008:8:489-503.

143. Harrison BA, Rattanarithikul R, Peyton EL, Mongkolpanya K. Taxonomic changes, revised occurrence records and notes on the Culicidae of Thailand and neighboring countries. Mosq Syst. 1990 (1991);22:196-227

144. Rattanarithikul R, Green CA. Formal recognition of the species of the Anopheles maculatus group (Diptera: Culicidae) occurring in Thailand, including the descriptions of two new species and a preliminary key to females. Mosq Syst. 1987;18:246-78. 
145. Belkin JN. The mosquitoes of the South Pacific (Diptera, Culicidae), vol. 1 and 2. Berkeley and Los Angeles: University of California Press; 1962.

146. Harbach RE. Culex pipiens: species versus species complex taxonomic history and perspective. J Am Mosq Control Assoc. 2012;28:10-23.

147. Tanaka K. Studies on the pupal mosquitoes of Japan. Genus Lutzia, with establishment of two new subgenera, Metalutzia and Isulalutzia (Diptera, Culicidae). Jpn J Syst Entomol. 2003;9:159-69.

148. Milligan S. Introductory speech by the agricultural adviser. In: Fletcher TB, editor. Proceedings of the fourth entomological meeting held at pusa on the 7th to 12th February 192. Calcutta: Superintendent Government Printing; 1921. p. 1-13.

149. Harbach RE, Howard TM. Corrections in the status and rank of names used to denote varietal forms of mosquitoes (Diptera: Culicidae). Zootaxa. 2007; 1542:35-48.

150. Thurman EB. A contribution to a revision of the Culicidae of northern Thailand. Univ Maryland Agr Exp Sta Bull. 1959;A100:1-182.

Submit your next manuscript to BioMed Central and we will help you at every step:

- We accept pre-submission inquiries

- Our selector tool helps you to find the most relevant journal

- We provide round the clock customer support

- Convenient online submission

- Thorough peer review

- Inclusion in PubMed and all major indexing services

- Maximum visibility for your research

Submit your manuscript at www.biomedcentral.com/submit
Biomed Central 